\title{
İstanbul Üniversitesi - Cerrahpaşa Orman Fakültesi Kampüs Florası Üzerine Bir Araştırma
}

\author{
Merve TANFER ${ }^{1}$, Ş.Doğanay YENER ${ }^{2 *}$ \\ ${ }^{1}$ İstanbul Üniversitesi-Cerrahpaşa, Lisansüstü Eğitim Enstitüsü, Peyzaj Mimarlığı Doktora Programı, İstanbul \\ 2 İstanbul Üniversitesi-Cerrahpaşa, Orman Fakültesi, Peyzaj Mimarlığı Bölümü, 34473, Bahçeköy-İstanbul
}

\section{Öz}

Nüfus ve yapılaşmanın kontrolsüz artışıyla kentsel yeşil alanların yanı sıra bilimsel amaçlı olarak da hizmet veren arboretumların, botanik bahçelerinin, üniversite kampüs alanlarının da sahip oldukları doğal varlık çeşitliliği kentsel ekosistemin önemli bir parçası haline gelmiştir. Ekolojik eğitim, genel eğitimin ayrılmaz bir parçasıdır. Özellikle ekolojik temelli meslek disiplinlerinin eğitim aldığı kurumlarda biyolojik çeşitliliğin zenginliği daha ön plana çıkmaktadır. Bitkilerin tanınması, özelliklerinin ve ekolojik isteklerinin bilinmesi, bu meslek disiplinlerinin uygulama sürecinde etkin kullanım, yenilikçi, sürdürülebilir çalışmalar ortaya çıkarılabilmeleri için de önemlidir. Bu çalışmada, İstanbul Üniversitesi - Cerrahpaşa Orman Fakültesi kampüs alanının doğal ve egzotik bitki taksonlarının tespit edilmesi ve elde edilen verilerin değerlendirilmesi amaçlanmıştır. Yapılan literatür, arazi ve büro çalışmaları sonucunda kampüs alanında tespit edilen otsu ve odunsu bitki taksonları teşhis edilerek kayıt altına alınmıştır. Araştırma sonucunda 101 familya, 282 cinse ait 494 takson tespit edilmiştir. Kampüs alanı içerisindeki doğal bitki varlığı, yakın çevresi Belgrad Ormanı'nda gerçekleştirilen flora araştırmalarıyla karşılaştırılmıştır. Alanın familya düzeyinde $\% 69$, cins düzeyinde $\% 52$, takson düzeyinde $\% 32$ oranında Belgrad Ormanı'na benzerlik gösterdiği tespit edilmiştir. Ayrıca, alandaki egzotik odunsu bitki çeşitliliğini değerlendirmek için İstanbul'da peyzaj düzenlemelerinde kullanılan egzotik odunsu bitki taksonlarıyla karşılaştırma yapılmıştır. Bu karşılaştırma sonucunda takson düzeyinde İstanbul'da peyzaj düzenlemelerinde kullanılan odunsu bitki taksonlarının \%38'inin, familya düzeyinde ise \%78'inin kampüs sınırları içerisinde görülebileceği tespit edilmiştir.

Anahtar Kelimeler: Flora, kampüs, biyoçeşitlilik, İstanbul.

\section{A Research about the Istanbul University - Cerrahpasa Faculty of Forestry Campus Flora}

\begin{abstract}
With the uncontrolled increase of population and housing, the natural variety of assets possessed by arboretums, botanical gardens, university campus areas that serve scientific purposes as well as urban green areas has become an important part of the urban ecosystem. Ecological education is an integral part of general education. Especially in institutions where ecological-based vocational disciplines are trained, the richness of biological diversity comes to the fore. Recognition of plants, knowledge of their characteristics and ecological requirements are also important for the effective use of these occupational disciplines, innovative and sustainable studies. In this study, it was aimed to determine the natural and exotic plant taxa of the Istanbul University-Cerrahpasa, Faculty of Forestry campus area and to evaluate the obtained data. As a result of the literature, field and office works; the herbaceous and woody plant taxa of Istanbul University- Cerrahpasa Faculty of Forestry campus area has been identified and recorded. 494 taxa belonging to 282 genera and 101 families were determined. The presence of native plants in the campus area has been compared with flora researches in the Belgrad Forest which is its immediate surroundings. It has been determined that the area is similar to the Belgrad Forest at family level with $69 \%$ and $52 \%$ similar at genus level and $32 \%$ similar at taxon level. In addition, a comparision was made with exotic woody plant taxa used in landscape designs of Istanbul to evaluate the exotic woody plant diversity in the area. As a result of this comparison, it has been determined that $38 \%$ of them are similar at taxon level and $78 \%$ of them are similar at family level.
\end{abstract}

Keywords: Flora, campus, biodiversity, Istanbul.

\footnotetext{
*Sorumlu Yazar (Corresponding Author):

Ş.Doğanay YENER (Dr.Öğr.Ü.); İstanbul Üniversitesi-Cerrahpaşa, Orman Fakültesi, 


\section{Giriş}

Endüstrinin gelişmesi, hızlı ve kontrolsüz kentleşme ile büyük kentlerde ekolojik denge bozulmaktadır. Büyük kentlerin sanayileşme ve finansal gelişimlerin odak noktası haline gelmesi, yapılaşmanın kırsal alanlara doğru ilerlemeleri, kentsel yaşam ve kırsal alanlar arasındaki ilişkilerin zarar görmesine neden olmaktadır. Kentlerde artan yaşam talebi ve bununla birlikte sosyal, ekonomik, kültürel değişiklikler içerisindeki ve çevresindeki yeşil alanların tahrip olmasına hatta tamamen yok olmasına neden olmaktadır (Kuter ve Erdoğan, 2010; Pamay, 1978). Kentleşme yeşil alanları azaltır, mevcut habitatları parçalar ve giderek daha küçük parsellere böler. Bu da yerli bitki türlerinin yerel olarak yok olmasına ve yabancı bitki türlerinin yerini almasına neden olabilir. Kentleşme bu nedenle biyotik homojenizasyon ve tür kaybının önemli bir itici gücü olabilmektedir (Knapp vd., 2008; McKinney, 2006).

Dünya üzerinde birçok meslek disiplini biyoçeşitliliğin korunması ve sürdürülebilirliğinin sağlanarak gelecek nesillere aktarılması için gayret göstermektedir (Uzun, 1978). 1982 yılında Birleşmiş Milletler tarafindan yayınlanan "Dünya Doğa Şartlarında", ekolojik eğitimin genel eğitim sisteminin ayrılmaz bir parçası olduğu ve bunun mümkün olan en geniş şekilde yayılması belirtilmiştir. Aynı şartnamede bilimsel araştırmalarla doğa bilgisinin artırılması ve bu bilgileri yaymak için sürekli çaba gösterilmesinin gerekliliği vurgulanmıştır.

İstanbul kenti yaklaşık 2500 bitki taksonu ile oldukça zengin bitki çeşitliliğine sahiptir. Fiziki coğrafya koşulları bitki örtüsünün tür çeşitliliği ve yoğunluğunu belirleyen önemli unsurlardandır. İstanbul'un coğrafi konum olarak kıtalar ve denizler arasında yer alması, jeolojik yapısı, topoğrafyası ve iklimi bitkiler için farklı yaşam alanlarına olanak sağlamaktadır. Kentteki bitki çeşitliliğinde bu türleri barındıran; ormanlar, kayalıklar, çayırlıklar, sert yapraklı çalılıklar, fundalıklar, sulak alanlar, kıyı ve kara kumulları vb. habitatların çeşitliliği de önemli rol oynamaktadır (Özhatay vd., 2010).

Bitkiler, görsel, ekolojik ve fiziksel özellikleriyle yıllar boyu oluşturmuş oldukları deneyimler ve etkiler ile kültürel simgeler haline gelmiş, içerisinde bulunmuş oldukları peyzajı karakterize etmede etkin bir rol üstlenmişlerdir. Hem doğal hem de kültürel peyzajın en önemli bileşenlerinden biridir (Eroğlu, 2012).

Bitkiler kent bileşenlerinin en etkili halkalarından biridir. Geçmişten günümüze yapılan araştırmalara göre bitkiler, hava kirliliğini önleme, hava sıcaklığını dengeleme, enerji tasarrufu sağlama, nem sağlama ve nem oranını dengeleme, fauna ve floraya yaşam ortamı oluşturma, gürültü kirliliğini azaltma, rüzgar, toz ve sera gazı etkilerini azaltma ve 1şık yansımalarını önleme gibi işlevleriyle kent ekosistemine çok önemli katkılar sağlamaktadır. Özellikle metropol kentlerde yer alan yeşil alanlar çevresindeki alanın değerini artırarak ekonomiye katkı sağlarlar. Bunların yanı sıra bitkilerin peyzaj onarım tekniği açısından erozyon önleme, maden - sanayi tesisi alanlarının 1slahı, çığ - heyelan önleme, toprağı 1slah etme gibi önemli fonksiyonları bulunmaktadır. Ayrıca bitkiler; estetik algı yaratma, perdeleme, sınırlama, mekan oluşturma, yönlendirme, gölgeleme, vurgu, güvenlik gibi estetik ve fonksiyonel açılardan da kentin gelişimine katkıda bulunmaktadır. (Ürgenç, 1990; Yılmaz ve Irmak, 2004).

Meydanlar, kamu kuruluşlarının bahçeleri, kıyısal alanlar, kent parkları ve eğitim kurumlarının kampüsleri kentsel yeşil alanları oluşturan önemli potansiyel alanlardır (Tanrıverdi, 1975; Pamay, 1979). Özellikle üniversite kampüs alanlarının kent peyzajının etkin bir parçası olarak kentin siluetini ve yaşamını değiştirdiği, kent gelişimine değer kattığı düşünülmektedir. Kentsel ekosistem üzerindeki etkilerinin yanı sıra kampüsler öğrencilerin öğrenim süreleri boyunca yaşamlarını sürdürdükleri, meslekleriyle ilgili bilgi birikimlerini kazandıkları yerler ve günlük deneyim alanlarıdır (Yıldız ve Şener, 2006; Yılmaz, 2015).

Yüksek öğretim kurumlarının tesisleri çeşitli alanlarda uzmanlık eğitimi vermenin yanı sıra kullanıcılarına ve bulunduğu bölgedeki insanlara rekreasyon olanağı sağlamaktadır. Mesleki bilgi ve donanımların kazanıldığı eğitim kurumları tarafından kullanıcılara sunulan sanatsal, kültürel, sosyal ve sportif etkinlikler için uygun ortam ve tesis imkanları, kişilerin kendilerini geliştirme ve sosyal varlık olma sürecini hızlandıran en önemli etkenlerdir. Özetle kente çağdaş yaşam biçimi örnekleri ve ortamları sağlamakla da sorumludur. (Ertekin ve Çorbacı, 2010).

Dünya genelinde birçok yükseköğretim kurumunun kampüs alanı sınırları içerisinde eğitim ve araştırma amaçlı botanik bahçeleri, arboretumlar bulunmaktadır. İÜC. Orman Fakültesi kampüs sınırları içinde bir herbaryum, alana çok yakın mesafede Atatürk Arboretumu ile İÜC-OF. Eğitim ve Araştırma ormanı ve Belgrad ormanı yer almaktadir.

Bitki örtüsünün faydalı kullanımı, yenilikçi çalışmalar ve ürünler ortaya çıkarılabilmesi için çok iyi tanınması önemlidir. Flora konusunda yapılan arazi çalışmalarında lokal bölgelerdeki bitki türleri üzerine detaylı 
araştırmalar yapılarak temel oluşturulabilir. Bu amaçla İÜC-OF. Kampüsünde egzotik türlerin yanı sıra doğal türlerin ve peyzaj düzenlemelerinde etkin rol oynayan bitkilerin tanınması büyük önem taşır. Bu kapsamda İÜCOF. Kampüsünün bitki örtüsünün eğitim ve araştırma faaliyetlerini desteklemesi amacıyla planlanması ve geliştirilmesi için kampüs içerisinde bulunan bitki türleri tanınması, envanterinin oluşturulması öncelikli hedeflerden biridir. Araştırma alanı konumu Belgrad Ormanına yakın olması nedeniyle sınırları içerisindeki doğal tür çeşitliliği, eğitim-öğretim amaçlı kullanıldığı için alana getirilen yeni taksonlar doğrultusunda egzotik bitki çeşitliliği vurgulanmıştır. Bu araştırma ile İÜC-OF. Kampüsü doğal bitki örtüsü ilk defa kayıt altına alınmıştır.

Ülkemizin bazı şehirlerinde bulunan üniversite kampüs alanlarında mevcut bitki örtüsünün tespiti ile ilgili çalışmalar gerçekleştirilmiştir. Bitki örtüsü açısından incelenen üniversite kampüslerinden bazıları; Akdeniz Üniversitesi (Ünal ve Gökçeoğlu, 2003), Artvin Çoruh Üniversitesi (Şimşak, 2014), Balıkesir Üniversitesi (Sanön, 1998), Başkent Üniversitesi (Töre ve Erik, 2012), Bozok Üniversitesi (Y1lmaz, 2016), İnönü Üniversitesi (Mutlu ve Karakuş, 2015), Kafkas Üniversitesi (Yılmaz, 2012), Kahramanmaraş Sütçü İmam Üniversitesi (Yağmur, 2017), Uludağ Üniversitesi (Tarımcılar, 1992), Kırıkkale Üniversitesi (Nugay vd., 2007), Karadeniz Teknik Üniversitesi (Coşkunçelebi, 1995), Muğla Üniversitesi (Ceylan, 2007), Harran Üniversitesi (Parmaksız vd., 2006), Anadolu Üniversitesi (Türe ve Böcük, 2001), Trakya Üniversitesi (Salık, 2015), Uşak Üniversitesi (Deniz, 2008), Yeditepe Üniversitesi (Yücebaş, 2014)'dir. Yapılan bu floristik çalışmaların bazılarında sadece doğal bitki türleri, bazılarında ise doğal ve egzotik bitki taksonları bir arada incelenmiştir.

$\mathrm{Bu}$ çalışmada, İstanbul'un bitki çeşitliliği bakımından en zengin kampüs alanlarından biri olan İstanbul Üniversitesi-Cerrahpaşa Orman Fakültesi (IÜC-OF) kampüs alanı bitki örtüsünün incelenmesi amaçlanmıştır. Mevcut çalışma, (a) İ̈̈C-OF florasının tespit edilmesi, (b) nadir veya tehdit altındaki bitkilerin tespit edilmesi, (c) komşu Belgrad Ormanı ile floristik benzerliğinin karşılaştırılması ve (d) egzotik bitki benzerliğinin İstanbul'daki diğer kentsel yeşil alanlarla karşılaştırılması amaçlanmıştır. Bu çalışma İÜC-OF florasının ilk yayınlanmış kaydıdır.

\section{Materyal ve Metot}

\subsection{Materyal}

Çalışma kapsamında araştırma alanı olarak İstanbul Üniversitesi - Cerrahpaşa Orman Fakültesi Kampüs alanı seçilmiştir. Yapılan literatür araştırmaları ve Bahçeköy mahallesinin günümüzdeki yerleşim alanı göz önünde bulundurulduğunda, kampüs alanının geçmişte Belgrad Ormanı'nın sınırları içerisinde olduğu görülmektedir. Bu nedenle, araştırma alanımızın doğal verilerini ele alırken yakın mesafede yer alan Belgrad Ormanı verilerinden yararlanılmıştır. İstanbul Üniversitesi - Cerrahpaşa Orman Fakültesi Kampüsü, İstanbul ilinin kuzeyinde Sarıyer

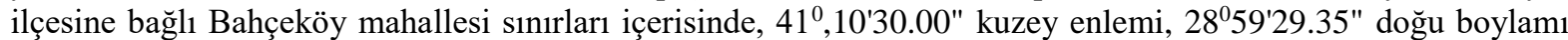
arasında yer almaktadır (Şekil 1). Alanın yükseltisi yaklaşık olarak 115-135 metre arasındadır. Alan içerisinde dokuz idari bina, bir kapalı spor salonu, atölye, otopark ve futbol sahasıyla birlikte yaklaşık 140 dönümlük bir arazi üzerine kurulmuştur.

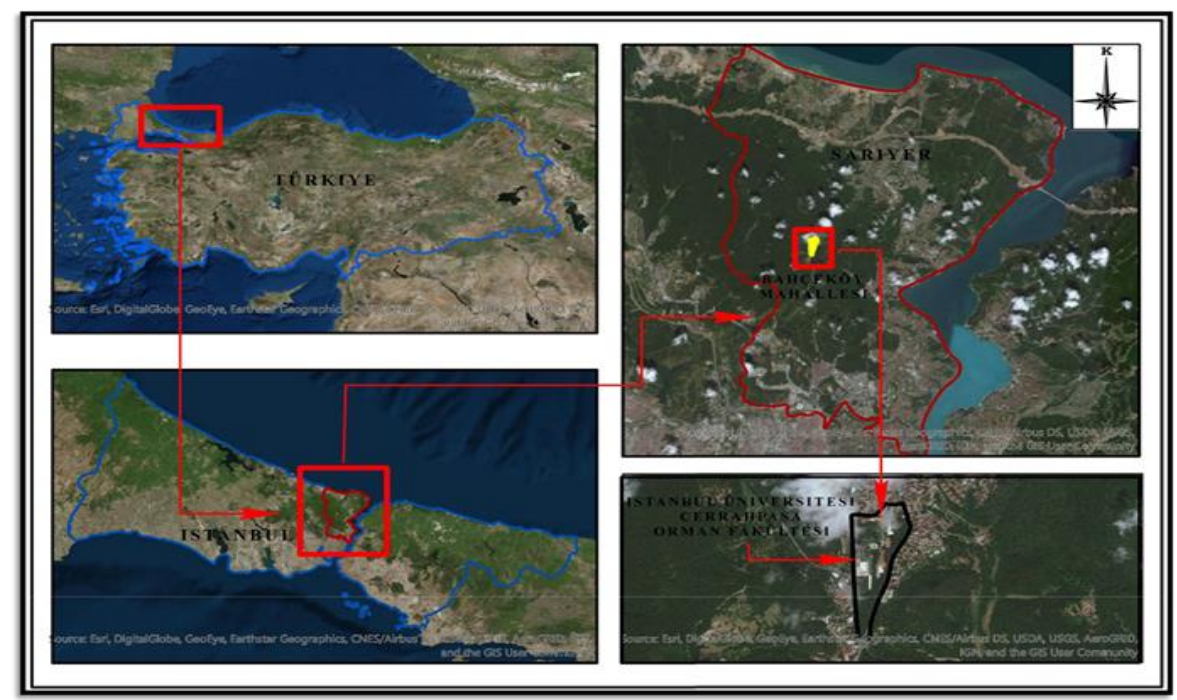

Şekil 1. Çalışma alanının konumu 
IUUC-OF. kampüsü kuzey-güney yönü doğrultusunda batı yönüne doğru eğimli bir topoğrafya üzerinde yer almaktadır. Alanın toprak yapısı "Ulusal Toprak Veritabanı” bilgilerine göre iğne yapraklı plantasyonun yer aldığı bölgede sı̆̆ ve taşlı kireçsiz orman toprağı, alanın geriye kalan büyük bölümünde sanayi ve yerleşim alanı olarak tespit edilmiştir.

İstanbul ili coğrafi konumu nedeniyle karasal, okyanusal, Akdeniz olmak üzere üç farklı lokal iklim tipine ve bu nedenle zengin bitki tür çeşitliliğine ev sahipliği yapmaktadır (Tunçkale, 1965; Dişli, 2016). Bölgenin iklim özelliklerinin ortaya konulmasında Bahçeköy’ün bağlı olduğu Sarıyer ilçesinin (1950- 2015) meteorolojik verilerinden yararlanılmıştır. Veriler Walter iklim diyagramı hazırlanarak ele alınmıştır.

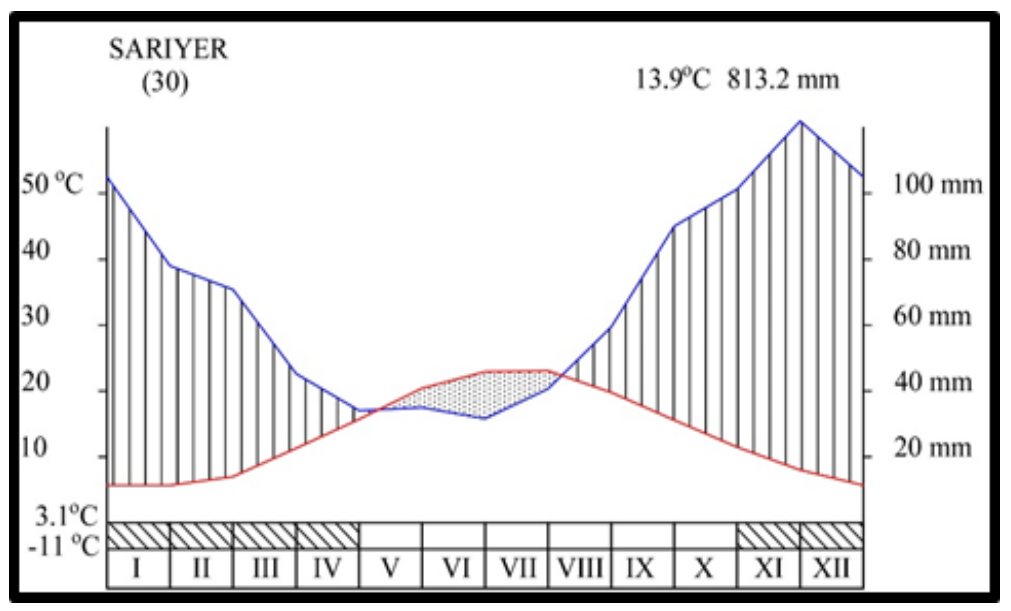

Şekil 2. Çalışma alanının Walter iklim diyagramı

Araştırma alanına yakın mesafedeki Belgrad Ormanı'nın vejetasyon durumu incelendiğinde; çeşitli ağaç ve boylu çalılardan oluşan "Yapraklı Orman Formasyonu" görülmektedir. Ayrıca orman "Pseudomaki" olarak adlandırılan, odunsu ve otsu karakterde bir çalı formasyonuyla çevrili bulunmaktadır (Yaltırık, 1966). Alanımızda Belgrad Ormanı'nda görülen bitki türlerinin yanı sıra farklı dönemlerde plantasyon çalışmaları ile getirilmiş iğne yapraklı ve geniş yapraklı odunsu bitkilerden oluşan bir odunsu bitki koleksiyonu ve düzenlenmiş alanlarda ağırlıklı olarak egzotik bitki türleri yer almaktadır.

Araştırma alanında yapılan arazi çalışmaları sırasında Erinaceus sp., Leucodon sp., Serpentes sp., Testudines sp., Lacertilia sp., Anura sp., Sciuridae sp., Canis sp., Felis sp. başlıca tespit edilen hayvan türleri arasındadır. Arslangündoğdu (2005)'un yapmış olduğu “İstanbul - Belgrad Ormanı’nın Ornitofaunası Üzerine Araştırmalar” adlı çalışmasından elde edilen verilere göre; kuşların göç yolu üzerinde yer alan kampüs alanı 39 farklı kuş türüne konaklaması için ev sahipliği yapmaktadır.

Günümüzde İÜC-OF.'sinde ön lisans, lisans, yüksek lisans ve doktora düzeyinde öğrenci yetiştirilmektedir. Kampüste aralarında Türkiye'nin en büyük herbaryumlarından (ISTO) birinin de olduğu eğitim, öğretim ve araştırma yapılan yedi bina bulunmaktadır. Aynı zamanda öğrencilerin uygulama çalışmaları yapabilmeleri için atölyeler ve sera alanı yer almaktadır.

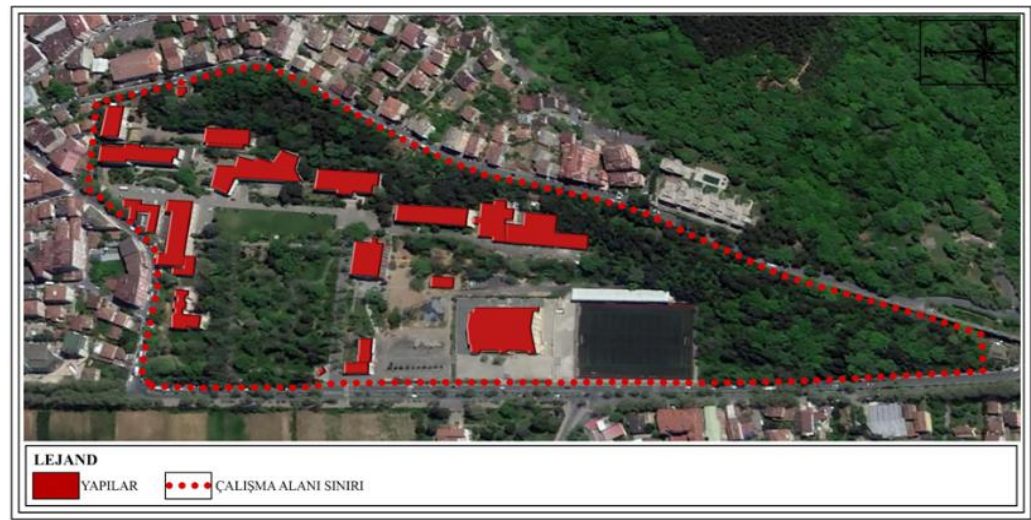

Şekil 3. Çalışma alanının krokisi 


\subsection{Metot}

Araştırmada, İÜC-OF. Kampüsü sınırları içinde bulunan bitki türlerinin tespit edilmesi, doğal türlerin yakın çevresiyle benzerlik ilişkisinin ortaya konulması ve alandaki egzotik bitki çeşitliliğinin kent ölçeğinde yapılmış çalışmalar baz alınarak karşılaş̧ıııılması amaçlanmıştır. Aynı zamanda bu araştırma ile alanın doğal bitki örtüsü ilk kez kayıt altına alınmaktadır. Bu kapsamda araştırmada izlenen aşamalar; çalışma alanı ve çevresindeki alanlarda daha önce yapılmış floristik çalışmaların belirlenmesi ve incelenmesi, ayrıca alana ve çevresine ait fiziki, kültürel verilerin belirlenmesi, floristik yapının teşhisini yapabilmek için gözlemler yapılması ve örnek toplanması amaçlı arazi çalışmaları, toplanan ve tespit edilen bitkilerin tespit edilmesi ve değerlendirilmesi şeklindedir.

\subsubsection{Literatür Araştırması}

Literatür araştırmaları çalışma alanının yakın çevresi ve kampüs alanları şeklinde iki kısımda yapılmıştır. Aynı zamanda araştırma sürecinde fikir sağlaması amacıyla yurtiçi ve yurtdışında yazılmış olan tez, kitap, makale, araştırma raporu, bildiri gibi kaynaklar temin edilmiş ve incelenmiştir. Bu çalışmalardan özellikle araştırma alanı yakın çevresini konu alan; Yaltırık (1966), Yönelli (1986), Yaltırık ve Efe (1989), Yaltırık vd. (1997), Kavgacı (2002), Erol (2005) ve Çolak vd. (2013) eserinden yararlanılmıştır. Kampüs alanının İstanbul genelinde kent peyzajında kullanılan egzotik odunsu taksonlar ile kampüs alanının karşılaştııılması aşamasında ise Yener (2012)'den yararlanılmıştır.

\subsubsection{Arazi Çalışması}

Bitki örneklerinin toplanması amacıyla 2015 - 2018 yılları arasında toplam 53 arazi çalışması yapılmıştır. Hemen her hafta bitki örneği toplamak, alandaki bitki örtüsündeki değişimi gözlemlemek amacıyla gerçekleştirilen arazi çalışmaları, vejetasyon dönemi olan aylarda (Mart, Nisan, Mayıs) daha fazla yoğunlaştırılmıştır. Örnekler toplanırken bitkinin üzerinde; çiçek, meyve, yaprak, sürgün, gövde, toprak altı kısmı (soğan, yumru, rizom vs.) ile tomurcuk gibi teşhis ve tanımlamada gerekli olan vejetatif ve generatif organların bulunmasına dikkat edilmiştir. Örnek toplamanın yanı sıra tüm türlerin teşhislerine yardımcı olması için fotoğrafları (meyvesi, yaprağı, çiçeği) çekilmiștir. Arazi çalışmaları sırasında örnek alanlardan toplam 558 adet bitki örneği toplanmıştır. Tüm bitki örnekleri preslenerek, tekniğine uygun bir şekilde kurutulmuş ve teşhise hazır hale getirilmiştir. Arazi çalışmalarında elde edilen veriler "Bitki Teşhis Kartı" olarak isimlendirilen arazi kartlarına işlenmiş̧ir.

\subsubsection{Büro Çalışması}

Örneklerin teşhis ve adlandırılması aşamasında temel kaynak olarak "Flora of Turkey and East Eagean Islands" 9 ciltlik seri (Davis, 1965-1985); 10. cilt Davis vd., (1988); 11. Cilt (Güner vd., 2000) eserleri ile teşhis sürecinde "Flowers of Europe" (Polunin, 1969), Belgrad Ormanı Vejetasyonunun Floristik Analizi ve Ana Meşcere Tiplerinin Kompoziyonu Üzerine Araştırmalar (Yaltırık, 1966), Otsu Bitkiler Sistematiği (Yaltırık ve Efe 1989) kaynaklarından ve yakın alanların florası üzerine daha önce yapılmış bilimsel çalışma ve tezlerden yararlanılmıştır.

Egzotik türlerin teşhisinde Pamay (1992; 1994)'ın Bitki Materyali I, II, III eserlerinden, Tarih Boyunca İstanbul'un Park Bahçe Koruları Egzotik Ağaç ve Çalıları (Yaltırık vd.,1997) çalışmasından, internet ortamında "Missouri Botanical Garden", "KEW Herbarium Catalogue", "Royal Horticultural Society", "USDA Natural Resources Conversation Service" sitelerinden faydalanılmıştır. Ayrıca bitki teşhisi sürecinde yerli ve yabancı kitaplardan, yurtdışındaki üniversitelerin, enstitülerin, botanik bahçesi ve arboretumların web adreslerinden yararlanılmıştır.

Morfolojik terimlerin çevirisinde İngilizce-Türkçe Botanik Kılavuzu (Baytop, 1998) ve Botanical Latin (Stearn, 1983) eserlerinden faydalanılmıştır. Bitkilerin isimlerinin yazılışı ve otör bilgileri için; familya, cins, tür, alttür bazında Latince bilgilerin yer aldığ 1 "The International Plant Names Index (IPNI, 2009)" adlı online veri tabanından, güncel familya isimlerini kontrol etmek için "The Euro+Med Plantbase Project" ve "The Plant List" veri tabanlarından yararlanılmış ve teşhis edilen bitkilerin listesi cins adlarına göre alfabetik olarak sınıflandırılmıştır.

Araştırma alanında tespit edilen türlerin tehlike kategorilerinin belirlenmesinde Türkiye Bitkileri Kırmızı Kitabı (Ekim vd., 2000)'ndan yararlanılmıştır. 


\section{Bulgular ve Tartışma}

Kampüs alanında 2015 - 2018 yılları arasında yapılan arazi çalışmaları sonucunda elde edilen veriler, tablolar ile açıklanmış ve grafikler ile desteklenerek sunulmuştur.

\subsection{Floristik Analiz}

Alanda yapılan arazi çalışmaları ve toplanan bitki örneklerinin teşhisi sonucunda 2'si Pteridophyta, 99'u Spermatophyta grubunda olmak üzere 101 familyaya ait 282 cins ve 494 bitki taksonu tespit edilmiştir. 494 bitki taksonunun 398'i tür, 20'si alttür, 72'si kültivar, 4'ü varyete düzeyindedir.

Tespit edilen taksonlardan Spermatophyta sınıfına giren familyalar tohum yapısına göre tekrar alt sınıflara ayrıldığında 7 familyanın Gymnospermae, 92 familyanın Angiospermae alt sınıfına ait olduğu belirtilmiştir. Çalışma alanı içerisinde kayıt edilen türlerde Gymnospermae sınıfına ait 7 familyada 61 takson yer almaktadır (Şekil 4).

Angiospermae sınıfina ait familyalardan Rosaceae, Fabaceae, Poaceae, Compositae, Lamiaceae, Sapindaceae, Oleaceae, Fagaceae, Plantaginaceae, Brassicaceae alanda en fazla takson sayısına sahip familyalar olarak 92 familya içerisinde ön plana çıkmaktadır (Şekil 5).

Kampüs alanında tespit edilen toplamda 101 familya içerisinde en fazla sayıda takson içeren ilk on familya 47 takson ile Rosaceae, 31 takson ile Fabaceae, 28 takson ile Cupressaceae, 25 takson ile Poaceae, 24 takson ile Compositae, 24 takson ile Pinaceae, 18 takson ile Lamiaceae, 16 takson ile Sapindaceae, 15 takson ile Oleaceae, 12'şer takson ile Fagaceae ve Plantaginaceae olarak belirtilmiştir.

Teşhis edilen bitki örnekleri içerisinde Acer cinsi 13 takson ile en fazla sayıda taksona sahip cinstir. Quercus cinsi 10 takson, Pinus cinsi 10 takson, Veronica cinsi 7 takson, Trifolium cinsi 7 takson, Juniperus cinsi 7 takson, Chamaecyparis ve Ligustrum cinsleri 6'şar takson içermektedir (Şekil 6).

277 doğal, 217 egzotik taksonun yer aldığı kampüs alanında 368 takson geniş yayılışlı ve fitocoğrafik bölgesi bilinmeyen, 86 takson Avr. - Sib. elementi, 33 takson Akdeniz elementi, 1 takson İran - Turan elementi, 6 takson kozmopolit yayılış gösteren bitki olarak tespit edilmiştir (Şekil 7).

Çalışmada tespit edilen 494 taksonun 296'sı odunsu, 198'i otsu bitkidir. Bitkiler formlarına göre ağaç, ağaçcık, çalı, sarılıcı, otsu bitki, eğrelti olmak üzere altı grupta sınıflandırılmıştır. Ağaç grubunda 126, ağaçcık da 43, çalıda 108, sarılıcı bitkilerde 22, otsu bitkilerde 193, eğrelti grubunda 2 takson tespit edilmiştir (Şekil 8). Alanda teşhis edilen odunsu bitki formlarının 134'ü herdem yeşil, 11'i yarı herdem yeşil, 151'i yaprağını döken bitkilerden oluşmaktadır (Şekil 9). Alanda yapılan çalışmalarda bazı sarılıcı bitkiler ve eğrelti türleri de dahil olmak üzere 198 adet otsu bitki kaydı yapılmıştır. Bunlardan 182 takson tür bazında, 14 takson alttür, 1 takson kültivar ve 1 takson varyete olarak ifade edilmiştir.

Çalışmada tespit edilen 494 bitki taksonunun 217 adedi (\%44) egzotik, 277 adedi (\%56) ise İstanbul'un doğal bitki taksonları içerisinde yer almaktadır (Şekil 10).

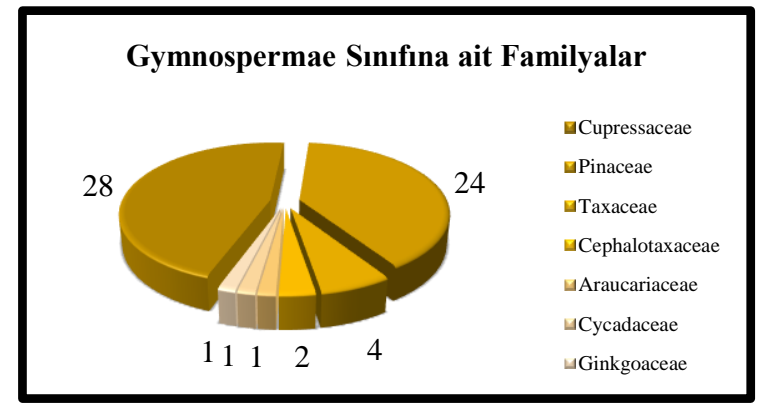

Şekil 4. Gymnospermae sınıfına ait familyalar

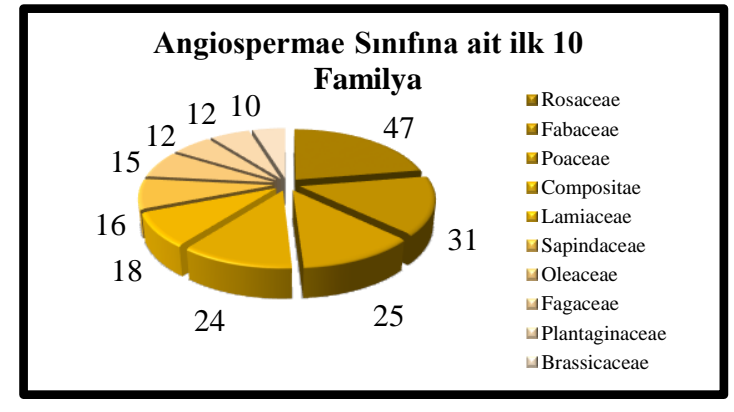

Şekil 5. Angiospermae sınıfına ait ilk 10 familya 


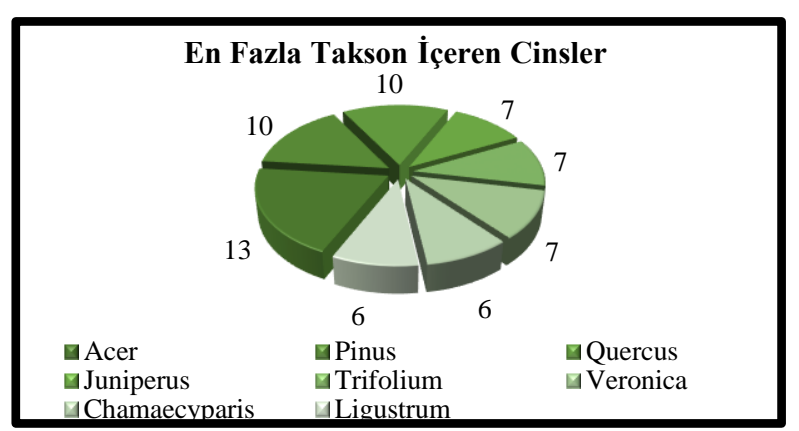

Şekil 6. En fazla takson içeren cinsler

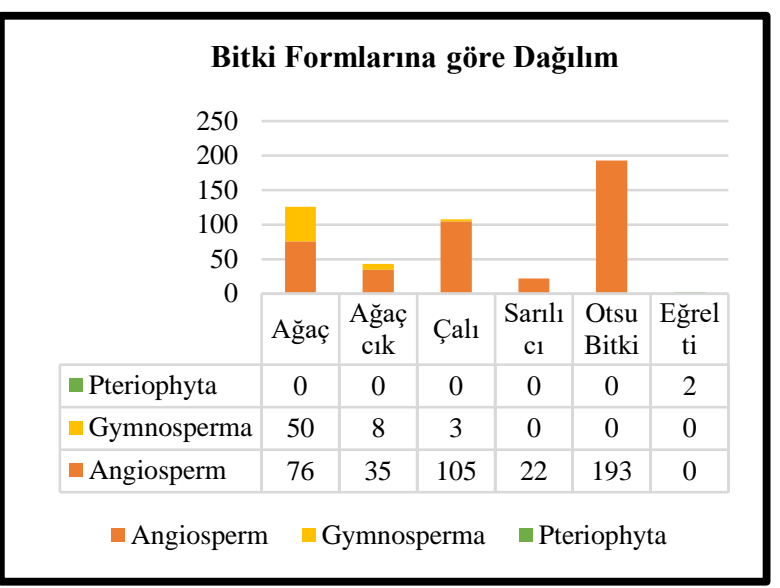

Şekil 8. Bitkilerin formlarına göre dağılımı

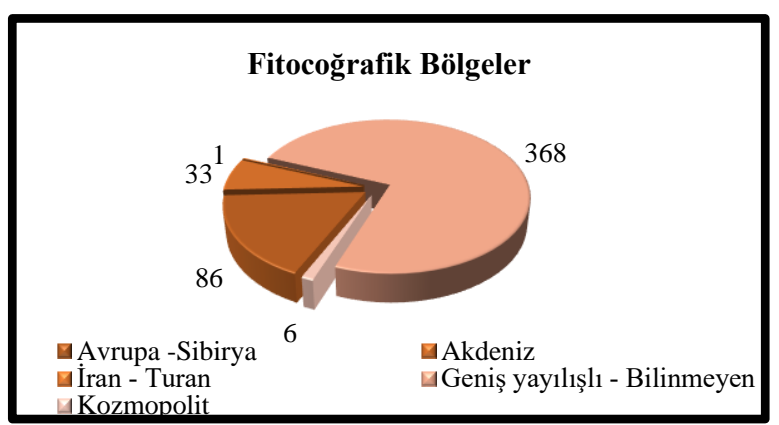

Şekil 7. Bitkilerin fitocoğrafik bölgelere dağılımı

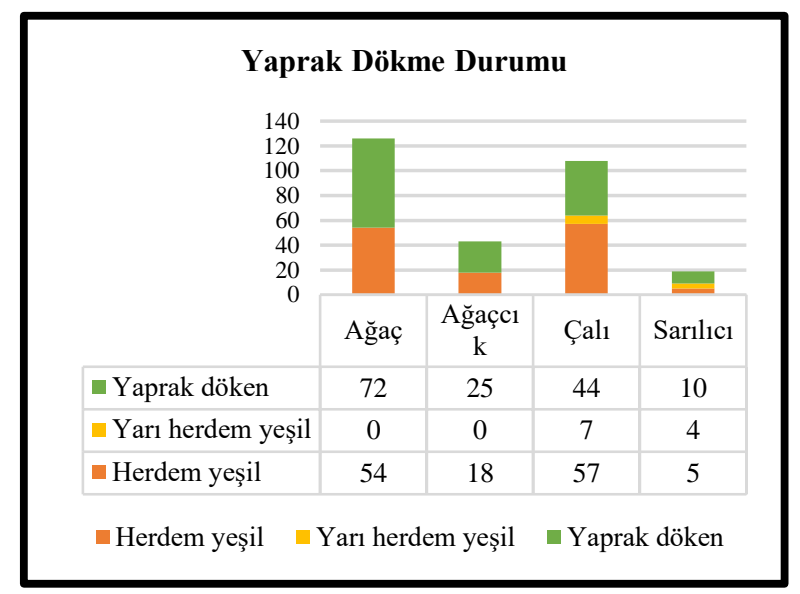

Şekil 9. Bitkilerin yaprak dökme durumu

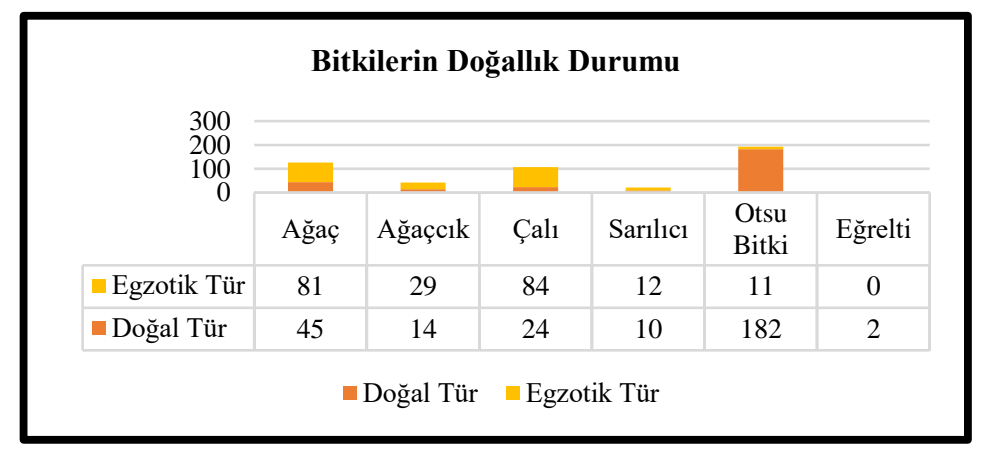

Şekil 10. Bitkilerin doğallık durumu

\subsection{Tehlike Kategorilerine Göre Dağılım}

Ekim vd. (2000)'nın eseri olan “Türkiye Bitkileri Kırmızı Kitabı” verilerine göre alanda tespit edilen 70 taksonun tehlike durumları değerlendirildiğinde alanda bulunan 4 taksonun zarar görebilir (VU), 1 taksonun da en az endişe verici (LR(lc)) kategorisinde olduğu belirtilmiştir.

Tablo 1. Türkiye kırmızı bitkileri kitabına göre tehlike durumları

\begin{tabular}{lc}
\hline Takson Adı & Tehlike Kategorisi \\
\hline Acer pseudoplatanus L. & VU \\
Albizia julibrissin Durazz. & VU \\
Ilex aquifolium L. & VU \\
Liquidambar orientalis Mill. & VU \\
Taraxacum turcicum Soest & LR (lc) \\
\hline
\end{tabular}


Tespit edilen bitkiler endemizm açısından incelendiğinde, kampüste bulunan odunsu türlerden Liquidambar orientalis Türkiye için endemik, Taraxacum turcicum ise İstanbul için endemik bitki türleri arasındadır. Alanda bulunan bitkilerin endemizm oranı \%0,41 olarak belirlenmiştir.

2014 yılında Çevre ve Şehircilik Bakanlığı'nın 2863 sayılı “Anıt ağaçları tespit, tescil ve bakım” kanunu kapsamında ve İstanbul Büyükşehir Belediyesi tarafından yürütülen çalışmayla "İstanbul'un Doğal Mirası Anıt Ağaçları" kayıt altına alınmıştır. Elde edilen verilere göre, kampüs alanında yer alan odunsu bitkilerden 6'sı mutlak surette korunması ve doğal miras olarak gelecek nesillere bırakılması zorunlu olan anıt ağaç statüsündedir. 19'u da korunmasında fayda görülen korunmaya değer ağaç statüsünde bulunmaktadır. Bu verilere göre kampüs alanı içerisinde 504 yaşında Quercus robur, 332 yaşında ve 286 yaşında 2 adet Pinus pinea, 261 yaşında Pterocarya fraxinifolia, 235 yaşında Calocedrus decurrens ve 181 yaşında Quercus rubra anıt ağaç statüsünde yer almaktadir.

\subsection{IÜC-OF. Kampüsü Bitki Örtüsünün Belgrad Ormanı ile Karşılaştırılması}

IÜC-OF. Kampüs alanı 19. yüzyıldan bu yana ormancılık ve ekolojik temelli bilimsel konularda eğitim ve uygulama hizmeti vermektedir. Kampüs alanı literatür kaynaklarından edinilen bilgilere göre geçmiş yıllarda Belgrad Ormanı sınırları içerisinde bulunmaktadır. Kentleşmenin orman alanı sınırları içerisine hızla ilerlemesi sonucu eskiden orman sınırları içinde kalan alanlar günümüzde çok farklı amaçlara hizmet etmektedir. Orman ekosistemi ile bağlantısı her geçen gün giderek azalmaktadır. Yaltırık (1966) tarafından, Belgrad ormanındaki doğal bitki türlerini konu alan doktora tez çalışmasında 86 familyaya ait tür, alttür ve varyete olmak üzere 415 takson tespit edilmiştir. Bunların 20'si liken ve yosunlar (Thallophyta, Bryophyta), 14'ü atkuyrukları ve eğreltiler (Pteridophyta), 1'i açık tohumlu (Gymnospermae), 297'si kapalı tohumlu (Angiospermae) Dicotyledoneae, 83'ü kapalı tohumlu Monocotyledoneae'dur.

Kampüs alanı ve yakın çevresi olarak kabul ettiğimiz Belgrad Ormanı verileri ile karşılaştırma yaparken liken ve yosun (Thallophyta, Bryophyta) taksonları çalışma kapsamımızın dışında bırakılmıştır. Aynı zamanda çalışma verileri son dönem bitki sistematiğinde yapılan değişikliklere uyarlanarak (familya isim değişikliği, familya değişikliği), tekrar gözden geçirilmiş ve güncellenmiştir. Alanımızda yapılan plantasyon ve düzenleme çalışmalarından sonra doğal tür açısından çevresindeki doğal orman ekosistemiyle ne kadar benzerlik gösterdiğini tespit etmek amacıyla verilerin karşılaştırılması aşamasında sadece tespit edilen doğal türler ele alınmıştır. Buna göre; 72 familya, 182 cinse ait 277 doğal bitki taksonu ile alan doğal vejetasyon özelliğini halen korumaktadır. Belgrad Ormanı verileriyle kampüs alanı arasında familya düzeyinde yapılan karşılaştırmada, sayısal değerlere bakıldığında orman ekosisteminin sahip olduğu bitki çeşitliliğine çok yakın düzeyde bir biyoçeşitliliğin alanda mevcut olduğu görülmektedir.

Tablo 3. Çalışma alanı ile Belgrad Ormanı karşılaştırması

\begin{tabular}{ccccccc}
\hline $\begin{array}{c}\text { Alanın } \\
\text { Adı }\end{array}$ & Familya & Cins & Takson & Angiospermae & Gymnospermae & Pteridophyta \\
\hline $\begin{array}{c}\text { Belgrad } \\
\text { Ormanı }\end{array}$ & 81 & 257 & 395 & 380 & 1 & 14 \\
ÏÜC-OF. & 72 & 182 & 277 & 260 & 15 & 2 \\
Kampüsü & 72 & & & & \\
\hline
\end{tabular}

İki alan arasında yapılan flora çeşitliliği karşılaştırmasına göre, alandaki doğal bitki türleri familya bazında 56 ortak familya ile \%69 oranında Belgrad Ormanı ile benzerlik göstermektedir. Cins bazında incelediğimizde ise alanda tespit edilen 182 cinsin 134'ünü Belgrad Ormanı'nda olduğu gibi araştırma alanında da görmemiz mümkündür. Cins açısından alanın yakın çevresine benzerlik oranı \%52'dir. Benzerlik düzeyini takson düzeyinde ele aldığımızda ise Belgrad Ormanı'nda bulunan doğal bitki türlerinden 128'inin kampüs alanında da yer aldığı tespit edilmiştir.

Araştırma alanı doğal tür düzeyinde yakın mesafede bulunan orman ekosistemiyle takson bazında \%32 oranında benzerlik göstermektedir. Familya düzeyindeki çeşitliliğin yüksek olması eğitim - araştırma açısından önemli bir konudur. Eğitim sürecinde aynı familyada yer alan bitki taksonlarının bulunması; genel karakter, çiçek, meyve, tohum gibi hortikültürel özelliklerinin karşılaştırmalı olarak öğrenilmesi için önemli bir firsattır. 


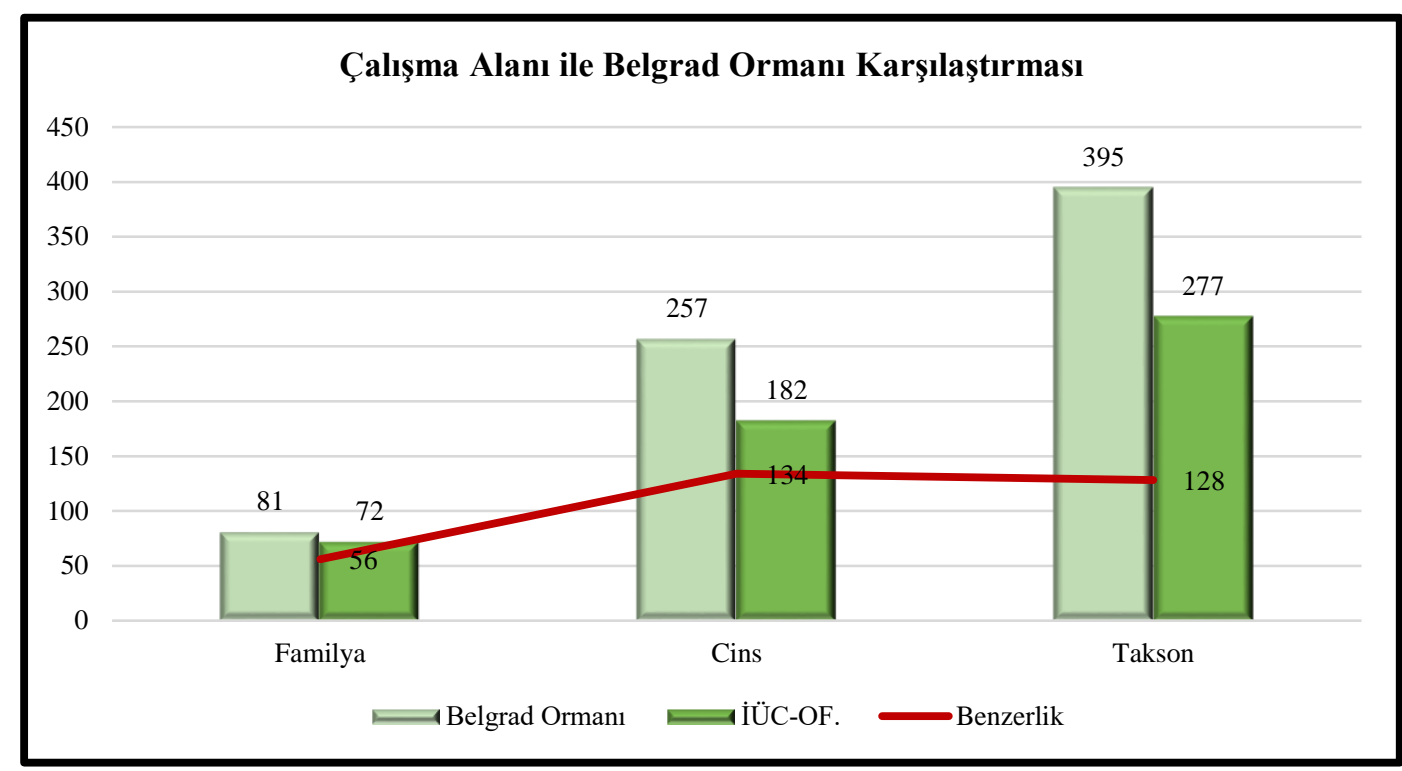

\section{4. iÜC-OF. Kampüsünün İstanbul'da Peyzaj Düzenlemelerinde Tercih Edilen Egzotik Odunsu Bitki Türleri İle Karşılaştırılması}

Yener (2012)'nin çalışmasında, kent çapında peyzaj düzenlemelerinde tercih edilen odunsu bitkileri teşhis etmek amacıyla 50 örnek alan belirlenmiş ve 73 familya 193 cinse ait 588 takson tespit edilmiştir. Bunlardan 176 takson doğal tür, 412 takson egzotik tür olarak kayıt altına alınmıştır. Çoban vd. (2020)'nin çalışmasında ise İstanbul genelinde yeşil alan tipleri arasında egzotik bitkiler açısından en yüksek oranın \%71 ile ev bahçelerinde olduğu belirlenmiştir.

İstanbul genelinde kullanılan egzotik taksonlar ile araştırma alanında yer alan egzotik taksonların karşılaştırılmasıyla elde edilen verilere göre, araştırma alanında tespit edilen 57 familyanın 54'ü kent genelinde yapılan düzenlemelerde kullanılmaktadır. Bu değer, kampüs alanındaki familyaların \%78'ine denk gelmektedir. Cins düzeyinde, 122 cinsin 112'si yani \%77'si benzerlik göstermektedir. Takson düzeyinde incelendiğinde ise 206 taksonun 155 ' $\mathrm{i}$ (\%38), kent genelinde birçok alanda gerçekleştirilen peyzaj düzenlemelerinde tercih edilmektedir.

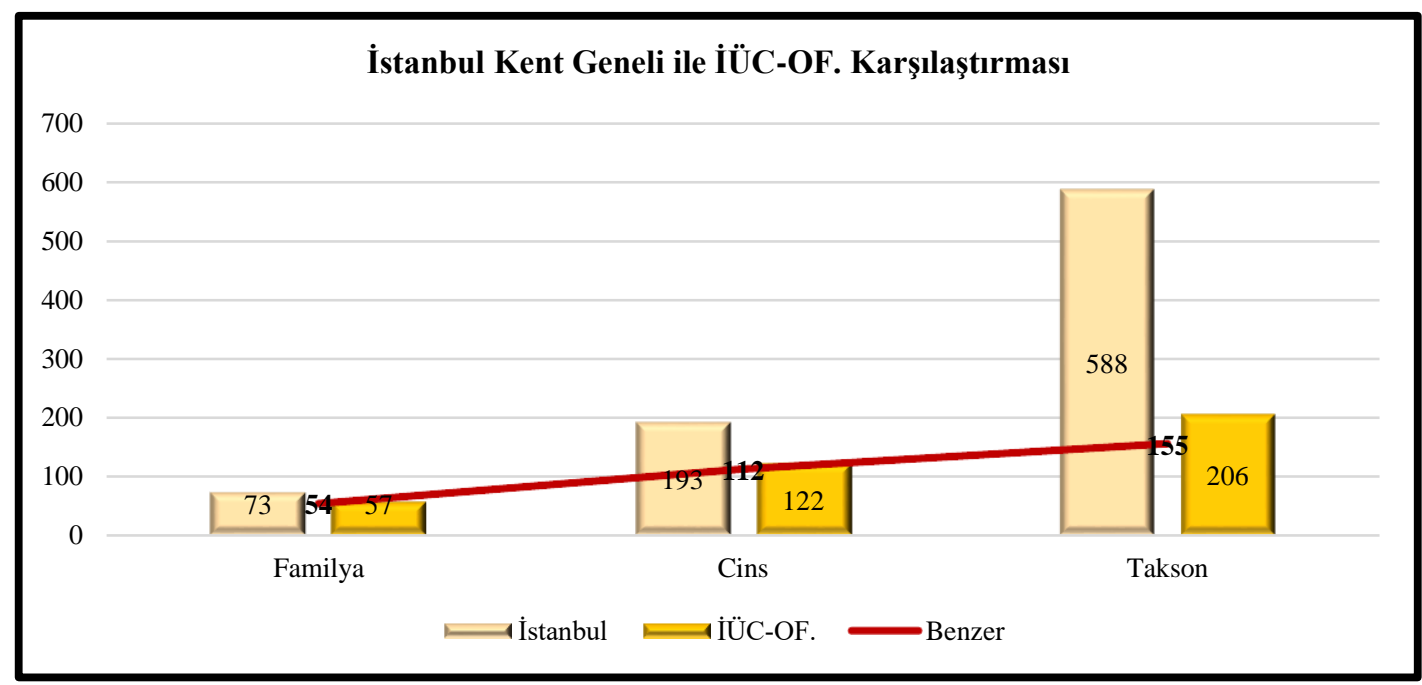

Araştırma alanımızda tespit edilen egzotik odunsu taksonlarını tür ve cins bazında değil sayısal veriler üzerinden değerlendirmek gerekirse, kent ölçeğinde tespit edilen egzotik bitki çeşitliliğinin takson düzeyinde \%38'ini, familya düzeyinde ise yaklaşı $\% 78$ 'ini tek bir alan olarak kampüs sınırları içinde görmek mümkündür. Bu durum bitki üzerine araştırma yapan, eğitim alan araştırmacı ve öğrenciler için inceleme ve gözlem yapabilmeleri açısından çok büyük bir firsat demektir. 


\section{Sonuç ve Öneriler}

Bitki örtüsü ekosistemdeki dengenin merkezidir. Dünya çapında ekosistemde meydana gelen ve geri dönüşü olmayan zararlar nedeniyle doğal yaşam, özellikle doğal bitki türleri her gün biraz daha önem kazanmaktadır. Uluslararası sözleşmelerde doğal türleri korumak ve sürdürülebilirliklerini sağlamak için sürekli yeni çalışmalar ve düzenlemeler yapılmaktadır. Kampüs alanlarındaki biyoçeşitlilik ve doğal alanların zenginliği, bilimsel ve ekolojik açıdan büyük önem taşımaktadır. Özellikle eğitim - araştırma hizmeti veren kampüslerde alanın florasının tanımlanması, kampüs sınırları içerisinde doğal çeşitliliğin korunmasına, alanı tahrip etmeden etkili ve verimli alan kullanım kararları verilebilmesine olanak sağlamaktadır. Bu çalışmada uzun yıllardır bilimsel faaliyet gösteren kampüs alanının doğal ve egzotik bitki varlığı ortaya konulmaya çalışılmıştır. Araştırma alanının küçük olması ve büyük bir kısmının kuruluşundan bugüne kadar geçen süre içinde yapılaşmış olması, farklı dönemlerde aktif kullanımın olduğu bölgelerde plantasyon ve düzenleme çalışmalarının yapılmasına rağmen çalışma sırasında 277 doğal bitki taksonu kayıt edilmiştir. Bu oran alandaki tür çeşitliliğinin \% 056 'sını ifade etmektedir.

Yapılan tespit ve teşhis çalışmaları sonucunda araştırma alanında tür çeşitliliğinin \%44'ünü 217 takson ile egzotik bitkiler oluşturmaktadır. Özellikle uzun süreli peyzaj düzenlemelerinde tercih edilen egzotik odunsu bitkiler, eğitimin yanı sıra kampüs alanı estetik ve görsel değerini de olumlu yönde etkilemektedir. Aynı zamanda hem doğal hem de egzotik olarak bu kadar fazla sayıda bitki türüne ev sahipliği yapması, bölgenin iklim ve toprak bakımından farklı bitki türlerinin gelişmesine ne kadar elverişli bir ortam olduğunun en önemli göstergesidir.

Farklı yaşam ortamları biyoçeşitlilik için önemlidir. Çalışma alanı küçük bir alan olmasına rağmen; yapraklı karışık plantasyon, iğne yapraklı plantasyon, sulak alan ve çevresi gibi minimal ölçekte farklı habitat tiplerinin bir arada bulunmasına imkan vermektedir. Habitat çeşitliliği, tür çeşitliliğini destekleyen bir biyoçeşitlilik bileşenidir. Bu doğrultuda kampüs alanında tür çeşitliliğini destekleyen önemli bir etkendir. İleriye dönük süreçte bu doğal çeşitliliğin devamı için mevcut habitatların korunması ve iyileştirilmesine yönelik çalışmalar yapılmalıdır.

Bahçeköy, kentin merkezinden uzakta Belgrad Ormanı'na yakın olmasından dolayı kent ekosistemi için geçiş zonu vazifesi görmektedir. Çevresindeki yapılaşma ve orman ekosisteminin bilinçsiz kullanımına rağmen kampüs alanı eğitim konusunun dişında bulunduğu konum için önemli yeşil alan niteliğindedir. İÜC-OF kampüsü sahip olduğu eşsiz bitki ve hayvan çeşitliliği ile biyoçeşitliliğin korunmasında ve doğa eğitimi alanında oldukça önemli bir role sahiptir. Bu nedenle alanda biyoçeşitliliğin korunması ve sürdürülebilirliğinin sağlanmasına yönelik yönetim planları oluşturulmalıdır. Bu şekilde öğrenciler başta olmak üzere, halkın doğa koruma ile ilgili katılımları sağlanacak ve kampüs alanı gibi zengin biyoçeşitliliğe sahip daha birçok alan koruma altına alınmış olacaktır.

\section{Teşekkür}

Bu çalışma, İstanbul Üniversitesi-Cerrahpaşa, Orman Fakültesi, Peyzaj Mimarlığı Bölümünde Yüksek Lisans Tezi olarak hazırlanan ‘İstanbul Üniversitesi- Cerrahpaşa Orman Fakültesi Kampüsü Bitki Örtüsü Üzerine Araştırmalar’ başlıklı çalışmadan yararlanılarak hazırlanmıştır.

\section{Kaynaklar}

1. Çoban, S., Yener, D., Bayraktar, S. (2020). Woody plant composition and diversity of urban green spaces in Istanbul, Turkey, Plant Biosystems - An International Journal Dealing with all Aspects of Plant Biology, DOI: 10.1080/11263504.2020.1727980

2. Ertekin, M., Çorbacı, Ö.M. (2010). Üniversite Kampüslerinde Peyzaj Tasarımı (Karabük Üniversitesi Peyzaj Projesi Örneği), Kastamonu Üniversitesi Orman Fakültesi Dergisi, Cilt:10, Sayı:1, Sayfa: 55-67.

3. Knapp, S., Kühn, I., Schweiger, O., Klotz, S. (2008). Challenging Urban Species Diversity: Contrasting Phylogenetic Patterns Across Plant Functional Groups in Germany, Ecol Lett, Cilt:11, Sayı:10, Sayfa:105410641.

4. Kuter, N., Erdoğan, E. (2010). Çankırı Kentsel Sit Alanının Bitki Varlığı Açısından Değerlendirilmesi, Tekirdă̆ Ziraat Fakültesi Dergisi, Cilt:7, Say1:2, Sayfa:105-111.

5. Mutlu, B., Karakuş, Ş. (2015). Floristic List Of Inönü University (Malatya) Main Campus Area, Hacettepe Journal of Biology And Chemistry, Cilt:43, Say1:2, Sayfa:73-89.

6. Nugay, Ö.Z., Duran, A., Doğan, B. (2007). Kırıkkale Üniversitesi Kampüs Florası, Selçuk Üniversitesi Fen Fakültesi Fen Dergisi, Say1:30, Sayfa: 79-92. 
7. Parmaksiz, A., Atamov, V., Aslan, M. (2006). The Flora of Osmanbey Campus of The Harran University, Journal of Biological Sciences, Sayı:6, Cilt:5, Sayfa:793,804, ISSN 1727-3048.

8. Töre, D., Erik, S. (2012). The Flora of Bağlıca Campus of Başkent University (Ankara), Hacettepe Journal Of Biology And Chemistry, Cilt:40, Sayı:3, Sayfa:267-291.

9. Türe, C., Böcük, H. (2001). The Flora of The Anadolu University Campus (Eskisehir-Turkey), Anadolu University Journal Of Science And Technology, Cilt:2, Say1:1, Sayfa: 83-95.

10. Ünal, O., Gökçeoğlu, M. (2003). Akdeniz Üniversitesi Kampüs Florası (Antalya-Türkiye), Akdeniz Üniversitesi Ziraat Fakültesi Dergisi, Cilt: 16, Say1: 2, Sayfa: 143-154.

11. Yılmaz, H., Irmak, M.A. (2004). Erzurum Kenti Açık - Yeşil Alanlarında Kullanılan Bitki Materyalinin Değerlendirilmesi, Ekoloji Dergisi, Cilt:13, Sayı: 52, Sayfa:9-16.

12. Yılmaz, S. (2015). Bir Kampüs Açık Mekanının Peyzaj Tasarımı: Süleyman Demirel Üniversitesi Orman Fakültesi Binas1, Kastamonu Üniversitesi Orman Fakültesi Dergisi, Sayfa: 297-307.

13. Arslangündoğdu, Z. (2005). İstanbul-Belgrad Ormanı'nın Ornitofaunası Üzerinde Araştırmalar, Doktora Tezi, İstanbul Üniversitesi Fen Bilimleri Enstitüsü.

14. Ceylan, O. (2007). Muğla Üniversitesi Yerleşke Florası, Yüksek Lisans Tezi, Muğla Üniversitesi Fen Bilimleri Enstitüsü.

15. Coşkunçelebi, K. (1995). Karadeniz Teknik Üniversitesi Kampüsünün Doğal Çiçekli Bitkileri, Yüksek Lisans Tezi, Karadeniz Teknik Üniversitesi Fen Bilimleri Enstitüsü.

16. Deniz, L. (2008). Uşak Üniversitesi 1 Eylül Kampüsü (Uşak) Florası ve Etnobotanik Açıdan Değerlendirilmesi, Yüksek Lisans Tezi, Afyon Kocatepe Üniversitesi Fen Bilimleri Enstitüsü.

17. Dişli, E. (2016). Belgrad Ormanı'nda Bazı Meşe Türü Gençliklerinin Silvikültürel Özellikleri, Yüksek Lisans Tezi, İstanbul Üniversitesi Fen Bilimleri Enstitüsü.

18. Eroğlu, E. (2012). Dağlık Alan Yol Koridorlarında Peyzaj Karakterini Belirleyen Doğal Bitki Kompozisyonlarının Tanımlanması; Ataköy-Sultan Murat-Uzun Göl Yol Güzergahı Örneği, Doktora Tezi, Karadeniz Teknik Üniversitesi Fen Bilimleri Enstitüsü.

19. Erol, U.E. (2005). Ekolojik Yaklaşımlı Peyzaj Planlaması Balabandere Vadisi Örneği, Doktora Tezi, İstanbul Üniversitesi.

20. Kavgacı, A. (2002). İ. Ü. Orman Fakültesi Araştırma Ormanının Florası ve Meşcere Kuruluşları, Yüksek Lisans Tezi, İstanbul Üniversitesi.

21. Salık, V. (2015). Trakya Üniversitesi’nin Florasının Tespiti, Yüksek Lisans Tezi, Trakya Üniversitesi Fen Bilimleri Enstitüsü.

22. Sanön, B. (1998). Balıkesir Üniversitesi Çağış Kampüsü ve Çevresinin Flora ve Vejetasyonu, Yüksek Lisans Tezi, Balıkesir Üniversitesi Fen Bilimleri Enstitüsü.

23. Şimşak, D. (2014). Artvin Çoruh Üniversitesi Seyitler Yerleşkesi ve Çevresinin Florası, Yüksek Lisans Tezi, Artvin Çoruh Üniversitesi Fen Bilimleri Enstitüsü.

24. Tarımcılar, G. (1992). Uludağ Üniversitesi Kampüs Alanı Florası, Yüksek Lisans Tezi, Uludağ Üniversitesi Fen Bilimleri Enstitüsü.

25. Uzun, G. (1978). Çukurova Üniversitesi Botanik Bahçesi Peyzaj Planlama İlkelerinin Saptanması ve Alan Kullanımı Üzerine Bir Araştırma, Doktora Tezi, Çukurova Üniversitesi Ziraat Fakültesi Peyzaj Mimarlığı Bölümü.

26. Yağmur, S. (2017). Kahramanmaraş Sütçü İmam Üniversitesi Avşar Kampüsü Tohumlu Bitkilerinin Çeşitliliği ve Sistematiği, Yüksek Lisans Tezi, Kahramanmaraş Sütçü İmam Üniversitesi Fen Bilimleri Enstitüsü.

27. Yener, D. (2012). İstanbul'da Peyzaj Düzenlemelerinde Kullanılan Odunsu Bitkiler Üzerine Araştırmalar, Doktora Tezi, İstanbul Üniversitesi Fen Bilimleri Enstitüsü.

28. Yılmaz, M.N. (2012). Kafkas Üniversitesi Kampüs Florası, Yüksek Lisans Tezi, Kafkas Üniversitesi Fen Bilimleri Enstitüsü.

29. Yılmaz, O. (2016). Bozok Üniversitesi Erdoğan Akdağ Kampüsü Florası, Yüksek Lisans Tezi, Bozok Üniversitesi Fen Bilimleri Enstitüsü.

30. Yönelli, V. (1986). Belgrad Ormanındaki Orman Toplumlarının Yapısı ve Silvikültürel Değerlendirilmesi, Doktora Tezi, İstanbul Üniversitesi Fen Bilimleri Enstitüsü.

31. Yücebaş, Z.D. (2014). Yeditepe Üniversitesi 26 Ağustos Yerleşkesi’nin (Ataşehir-İstanbul) Floristik ve Ekolojik Özellikleri, Yüksek Lisans Tezi, Marmara Üniversitesi Fen Bilimleri Enstitüsü.

32. Asan, Ü. (2014). İstanbul'un Doğal Mirası Anıt Ağaçlar - Avrupa Yakası, İstanbul Büyükşehir Belediyesi Park Bahçe ve Yeşil Alanlar Daire Başkanlığı Avrupa Yakası Park ve Bahçeler Müdürlüğü, İstanbul.

33. Baytop, A. (1998). Botanik Kılavuzu (İngilizce-Türkçe), İ.Ü. Yayın No:4058, İ.Ü. Eczacılık Fakültesi Yayınları, Yayın No: 70, 975-404-482-1.

34. Çolak, H.A. (Editör). (2013). Belgrad Orman - Bir Doğa ve Kültür Mirası, T.C. Orman ve Su İşleri Bakanlığı, I. Bölge Müdürlüğü - İstanbul, ISBN: 978-605-4610-27-3. 
35. Davis, P.H. (1965-1985). Flora of Turkey and The East Aegean Islands, Vol I-IX, Edinburgh University Press, Edinburgh.

36. Davis, P.H., Mıll, R.R. And Tan, K. (1988). Flora of Turkey and The East Aegean Islands (Supplement), Vol 10, Edinburgh University Press, Edinburgh.

37. Ekim, T., Koyuncu, M., Vural, M., Duman, H., Aytaç, Z., Adıgüzel, N. (2000). Türkiye Bitkileri Kırmızı Kitabı (Ĕgrelti ve Tohumlu Bitkiler), Türkiye Tabiatını Koruma Derneği, Van Yüzüncü Yıl Üniversitesi, ISBN: 975-93611-0-8.

38. Güner, A., Özhatay, N., Ekim, T. And Başer, K.H.C. (2000). Flora of Turkey and The East Aegean Islands (Supplement 2), Vol 11, University Press, Edinburgh.

39. Özhatay, N., Özhatay, E., Erdem, A.Ö. (2010). Şile’nin Doğal Bitkileri, Işık Üniversitesi Yayınları - 02, 1. Bask1, İstanbul, ISBN 978-975-6494-02-8.

40. Pamay, B. (1979). Park-Bahçe ve Peyzaj Mimarisi, İ.Ü. Orman Fakültesi Yayınları, İ.Ü. Yayın No: 2486, İstanbul.

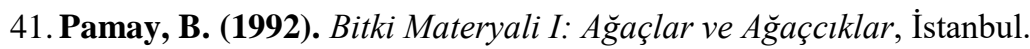

42. Pamay, B. (1993). Bitki Materyali II: Çiçekli Çalılar, Kaktüsler, Sarmaşıklar, Saz ve Kamışlar, Orhan Ofset, İstanbul.

43. Pamay, B. (1994). Bitki Materyali III: Park ve Bahçelerimizin Çiçekleri, Orhan Ofset, İstanbul.

44. Stearn, W.T. (1973). Botanical Latin, David \& Charles, Newton, Abbot, UK.

45. Yaltırık, F. (1966). Belgrad Orman Vejetasyonunun Floristik Analizi ve Ana Meşcere Tiplerinin Kompozisyonu Üzerinde Araştırmalar, O.G.M. Yayınlarından, Sıra No: 436, Seri No: 6, İstanbul.

46. Yaltırık, F., Efe, A. (1989). Otsu Bitkiler Sistematiği, İ.Ü. Orman Fakültesi Ders Kitabı, Orman Fakültesi Yayın No: 10, ISBN: 975-404-437-6, İstanbul.

47. Yaltırık, F., Efe, A., Uzun, A. (1997). Tarih Boyunca İstanbul'un Park Bahçe ve Koruları Egzotik Ă̆aç ve Çalıları, İsfalt Yayını, Yayın No: 4, ISBN: 975-8183-00-1, İstanbul.

48. URL-1 (2007). http://www.missouribotanicalgarden.org.html, (05.04.2019).

49. URL-2 (2007). http://apps.kew.org/herbcat/gotoHomePage.do.html, (05.04.2019).

50. URL-3 (2007). https://www.rhs.org.uk/plants/details?plantid=5211.html, (05.04.2019).

51. URL-4 (2007). https://plants.sc.egov.usda.gov/java/.html, (05.04.2019).

52. URL-5 (2007). http://www.ipni.org/ipni/plantnamesearchpage.do.html, (05.04.2019).

53. URL-6 (2007). http://ww2.bgbm.org/EuroPlusMed/query.asp.html, (05.04.2019).

54. URL-7 (2007). http://www.theplantlist.org/html, (05.04.2019).

55. URL-8 (2007). https://istatistik.yok.gov.tr/html, (05.04.2020). 